\title{
AZGP1 Gene
}

National Cancer Institute

\section{Source}

National Cancer Institute. AZGP1 Gene. NCI Thesaurus. Code C92505.

This gene plays a role in lipid catabolism. 